\title{
Characterization of pharmacological properties of methanolic seed and stem bark extracts of Ziziphus mauritiana (BAU Kul) using in-vitro and in-vivo animal (Swiss albino male mice) model
}

\author{
Md. Khokon Miah Akanda and A. H. M. Nazmul Hasan *i)
}

\begin{abstract}
Background: Ziziphus mauritiana belongs to family of Rhamnaceae, is an improved fast-growing variety of plum and seasonal fruit which is very popular and commonly known as "BAU Kul" in Bangladesh. This study was designed to evaluate the medicinal values of seed and stem bark extracts of Ziziphus mauritiana.

Methods: Antioxidant, thrombolytic, membrane stabilizing, cytotoxic and antimicrobial activities were characterized using in-vitro methods and anti-diarrheal, analgesic and hypoglycemic activities were evaluated in Swiss albino male mice. The coarse powder of the plant parts were extracted with methanol and methanol portion of the extract was evaporated naturally under room temperature. Then the dried plant extracts were undergone for subsequent investigation.

Results: Total phenolic and flavonoid content, and antioxidant capacity of stem bark extract were higher than seed extract. Both extracts had similar DPPH ( $\left(\mathrm{C}_{50}\right.$ of seed $4.53 \mu \mathrm{g} / \mathrm{ml}$ and stem bark $\left.4.13 \mu \mathrm{g} / \mathrm{ml}\right)$ and $\mathrm{NO}\left(\mathrm{IC}_{50}\right.$ of seed $5.92 \mu \mathrm{g} / \mathrm{ml}$ and stem bark $5.47 \mu \mathrm{g} / \mathrm{ml}$ ) free radicals scavenging potential and seed extract was most cytotoxic $\left(\mathrm{LC}_{50}=1.467 \mu \mathrm{g} / \mathrm{ml}\right)$. Stem bark extract showed higher thrombolytic and anti-inflammatory potential, and also exhibited $14 \mathrm{~mm}$ zone of inhibition against $S$. aureus. Stem bark extract showed highest anti-diarrheal $(75.68 \%$ defecation inhibition, $\left.p^{<} 0.001\right)$, analgesic (68.63\%writhing inhibition, $\left.p^{0} 0.001\right)$ and hypoglycemic activity (44.27\% blood glucose reduction after $3 \mathrm{~h}, p^{\mathrm{c} 0.001)}$ at $400 \mathrm{mg} / \mathrm{kg}$ body weight dose.
\end{abstract}

Conclusion: This study confirms good medicinal properties of selected plant parts. Further studies on isolation and characterization of its bioactive compounds are highly required.

Keywords: Z. mauritiana, Antioxidant, Anti-microbial, Thrombolysis, Anti-inflammatory, Cytotoxicity, Anti-diarrheal, Anti-diabetic

\footnotetext{
* Correspondence: nazmul_0155@yahoo.com

Department of Pharmacy, University of Asia Pacific, 74/A, Green Road, Dhaka 1205, Bangladesh
}

\section{Springer Open}

(c) The Author(s). 2021 Open Access This article is licensed under a Creative Commons Attribution 4.0 International License, which permits use, sharing, adaptation, distribution and reproduction in any medium or format, as long as you give appropriate credit to the original author(s) and the source, provide a link to the Creative Commons licence, and indicate if changes were made. The images or other third party material in this article are included in the article's Creative Commons licence, unless indicated otherwise in a credit line to the material. If material is not included in the article's Creative Commons licence and your intended use is not permitted by statutory regulation or exceeds the permitted use, you will need to obtain permission directly from the copyright holder. To view a copy of this licence, visit http://creativecommons.org/licenses/by/4.0/. 


\section{Introduction}

The biological resource of nature such as plants, animals and microorganisms can be used for social, environmental and therapeutic purposes. Wide ranges of pharmacological activities are recorded for many medicinal plants globally. Medicinal plants are the nature's gift to human beings to help them pursue a disease-free healthy life [1]. "BAU Kul" is known as Ziziphus mauritiana and belongs to family of Rhamnaceae. "BAU Kul" is a newly improved fast-growing variety of plum and sweet seasonal fruit which is very popular to the consumers of Bangladesh. The name "BAU" indicates its hybridization source, Bangladesh Agricultural University (BAU) which derived from cross-breeding local fruit from Bangladesh with jujube fruits from the Philippines, Somalia, India, Taiwan and China. The average weight of fruit is $90 \mathrm{~g}$ and seeds are small in size [2,3]. The seed and stem bark parts of Ziziphus mauritiana were included in our present study because there are very limited reports on the selected plant parts.

\section{Methods}

\section{Ethnomedicinal survey of Ziziphus mauritiana}

Local folk medicine practitioners were included to know the traditional usage pattern of Ziziphus mauritiana either single or combination with other plant parts in different ailments. Both male and female kavirajes of Gaibandha district of Bangladesh were included in this survey. Written Informed consent was obtained and those who refused to provide information were excluded from this study. A total of 10 kavirajes (folk medicine practioner) were interviewed and information was recorded. All the questions were asked in native language (Bengali) for their easy understanding.

\section{Collection and identification of the plant sample}

The seeds and stem barks part of Ziziphus mauritiana was collected from the BAU Kul garden of Gaibandha district of Bangladesh and identified by a taxonomist of Department of Botany, Jahangirnagar University, Savar, Dhaka.

\section{Preparation and extraction of the sample}

The plant parts were washed thoroughly in distilled water and sundried for 15 days and oven dried for 7 days at $40{ }^{\circ} \mathrm{C}$ and then it was grinded into coarse powder. Then plant parts were extracted by maceration extraction process using methanol [4]. $600 \mathrm{~g}$ of powder was taken and submersed into 2.51 of methanol and went through regular shaking for 14 days to prevent clump formation in order to ease of filtration. Then cotton filtration process was performed to get supernatant. The methanol portions from the extract evaporate naturally under the room temperature. The extracts were kept away from sunlight in a air conditioned room and preserved in a refrigerator at $2-8^{\circ} \mathrm{C}$.

\section{Phytochemical screening}

Phytochemical screening of the extracts were carried out for the detection of active components like carbohydrates, glucosides, saponins, steroids, flavonoids and alkaloids according to the standard protocols $[5,6]$.

\section{Antioxidant properties \\ Determination of total phenolic content}

Total phenolic contents of the extracts were determined by the Folin-Ciocalteu reagent method [7]. All of extracts and standard were diluted by serial dilutions as $(50 \mu \mathrm{g} / \mathrm{ml}$ to $250 \mu \mathrm{g} / \mathrm{ml})$ then, on each test tube containing $1 \mathrm{ml}$ of diluted solution of sample and standard, following reagent solutions were added $5 \mathrm{ml}$ folin-ciocalteu reagent (previously diluted with water $1: 10 \mathrm{v} / \mathrm{v}$ ) and $4 \mathrm{ml}$ (7.5\% sodium carbonate) of sodium carbonate. Samples were incubated at $20^{\circ} \mathrm{C}$ for $60 \mathrm{~min}$ and standard diluted solution reagent mixture was incubated at $20^{\circ} \mathrm{C}$ for 30 min. Absorbance of samples and standard were measured at $765 \mathrm{~nm}$ using UV-VIS spectrophotometer against blank. A typical blank solution contained the solvent used to dissolve the plant extract. The total content of phenol compounds in plant extracts in Gallic acid equivalents (GAE) was calculated using the following equation:

$$
\mathrm{C}=(\mathrm{c} \times \mathrm{V}) / \mathrm{m}
$$

Where,

$\mathrm{C}=$ total content of phenol compounds, $\mathrm{mg} / \mathrm{gm}$ plant extract, in GAE

$\mathrm{c}=$ the concentration of Gallic acid established from the calibration curve $(\mathrm{mg} / \mathrm{ml})$

$\mathrm{V}=$ the volume of extract in $\mathrm{ml}$

$\mathrm{m}=$ the weight of crude plant extract in gm

\section{Determination of total flavonoid content}

Aluminum chloride colorimetric method was used for flavonoids determination [8]. $1 \mathrm{ml}$ of plant extract or standard of different diluted $(25 \mu \mathrm{g} / \mathrm{ml}$ to $250 \mu \mathrm{g} / \mathrm{ml})$ concentrations solutions was taken in a test tube and 3 $\mathrm{ml}$ of methanol, $0.2 \mathrm{ml}$ of $10 \%$ aluminum chloride, 0.2 $\mathrm{ml}$ of $1 \mathrm{M}$ potassium acetate and $5.6 \mathrm{ml}$ of distilled water were added. It was incubated at room temperature for 30 min then absorbance of the reaction mixture was measured at $415 \mathrm{~nm}$ using UV-VIS spectrophotometer against blank (methanol). The total flavonoid contents of the plant extracts were expressed as $\mathrm{mg} / \mathrm{g}$ quercetin equivalent using the equation obtained from the reference standard quercetin. 


\section{Determination of total antioxidant capacity}

The total antioxidant capacity was evaluated by the phosphomolybdenum method [9]. $0.3 \mathrm{ml}$ of extract and sub-fraction in methanol, ascorbic acid used as standard $(25-400 \mu \mathrm{g} / \mathrm{ml})$ and blank (methanol) were combined with $3 \mathrm{ml}$ of reagent mixture separately and incubated at $95^{\circ} \mathrm{C}$ for $90 \mathrm{~min}$. After cooling to room temperature, the absorbance of each sample was measured at $695 \mathrm{~nm}$ against the blank. The antioxidant capacity is expressed as the $\mathrm{mg} / \mathrm{g}$ of equivalents of ascorbic acid and was calculated using the equation obtained from the reference standard ascorbic acid.

\section{DPPH free radical scavenging assay}

The free radical scavenging capacity of the extracts was determined using DPPH [10]. $1 \mathrm{ml}$ of plant extract or standard of different diluted concentration $(25 \mu \mathrm{g} / \mathrm{ml}$ to $400 \mu \mathrm{g} / \mathrm{ml}$ ) solutions were taken in test tubes and freshly prepared $2 \mathrm{ml}$ of $0.004 \%$ DPPH solution was added to each test tube to make the final volume of $3 \mathrm{~mL}$. The mixture was incubated at room temperature for $30 \mathrm{~min}$; the absorbance was read at $517 \mathrm{~nm}$ using UV-VIS spectrophotometer. Ascorbic acid was used as standard. Control sample was prepared containing the same volume without any extract or standard. Methanol was served as blank. Free radical scavenging activity of the extracts was evaluated as $\%$ inhibition and/or $\mathrm{IC}_{50}$ using the following equation:

$$
\text { \%inhibition }=\left(1-A_{1} / A_{0}\right) \times 100 \%
$$

Here,

$A_{1}=$ Absorbance of the extract or standard

$\mathrm{A}_{0}=$ Absorbance of the control

\section{Nitric oxide (NO) scavenging assay}

Nitric oxide scavenging assay was carried out using sodium nitroprusside [11]. This can be determined by the use of the Griess Illosvoy reaction. $4 \mathrm{ml}$ of each plant extracts or standard of different concentration solutions were taken and $1 \mathrm{ml}$ of Sodium nitroprusside, ( $5 \mathrm{mM}$ ) solution was added into the test tubes. The test tubes were incubated for $2 \mathrm{~h}$ at $30^{\circ} \mathrm{C}$ to complete the reaction. $2 \mathrm{ml}$ solution was withdrawn from the mixture and mix with $1.2 \mathrm{ml}$ of griess reagent and the absorbances of the solutions were measured at $550 \mathrm{~nm}$ using a spectrophotometer against blank. Typical control solutions contain the same solution mixture without plant extract or standard. Percentage inhibition of the NO free radical was measured by using the equation of $\%$ inhibition of the DPPH free radical.

\section{Cytotoxicity}

The cytotoxic property of the extract was evaluated using brine shrimp lethality test [12]. This investigation was carried out on Artemia salina (Brine shrimp). One spoon of cyst was hatched for $48 \mathrm{~h}$ in saline water, prepared by dissolving $38 \mathrm{~g} \mathrm{NaCl}$ into 1 $\mathrm{L}$ water and the cyst became living nauplii. Different concentrations eg. $800 \mu \mathrm{g} / \mathrm{ml}, 400 \mu \mathrm{g} / \mathrm{ml}, 200 \mu \mathrm{g} / \mathrm{ml}$, $100 \mu \mathrm{g} / \mathrm{ml}, 50 \mu \mathrm{g} / \mathrm{ml}, 25 \mu \mathrm{g} / \mathrm{ml}, 12.5 \mu \mathrm{g} / \mathrm{ml}$ and $6.25 \mu \mathrm{g} /$ $\mathrm{ml}$ of both seed and stem bark extract were prepared using dimethyl sulfoxide as solvent. Ten nauplii were taken in each test tube and finally volume was adjusted by saline water. In the present study vincristine sulfate was used as positive control. Vincristine is a very cytotoxic alkaloid and it was evaluated at very low concentrations eg. $25 \mu \mathrm{g} / \mathrm{ml}, 12.5 \mu \mathrm{g} / \mathrm{ml}, 5 \mu \mathrm{g} / \mathrm{ml}$, $1 \mu \mathrm{g} / \mathrm{ml}, \quad 0.5 \mu \mathrm{g} / \mathrm{ml}, \quad 0.25 \mu \mathrm{g} / \mathrm{ml}, \quad 0.125 \mu \mathrm{g} / \mathrm{ml}$ and $0.06 \mu \mathrm{g} / \mathrm{ml}$. $50 \mu \mathrm{l}$ of DMSO was added to each of three pre marked test tubes containing $4.9 \mathrm{ml}$ of simulated sea water and 10 shrimp nauplii was added to use as negative control groups. All the test tubes were kept in rest for $24 \mathrm{~h}$ and then counted for living and dead nauplii by using a magnifying glass against a black background. From this data, the percent (\%) of lethality was calculated for each concentration using the following equation-.

$$
\mathrm{Pt}=[(\mathrm{Po}-\mathrm{Pc}) /(100-\mathrm{Pc})] \times 100
$$

Where,

Po $=$ Observed mortality

$\mathrm{Pc}=$ Control mortality

The effectiveness or the concentration-mortality relationship of plant product is usually expressed as a median lethal concentration $\left(\mathrm{LC}_{50}\right)$ and determined by linear regression method from plotting \% mortality against correspondent log of concentration.

\section{Thrombolytic activity}

In-vitro thrombolytic activity method was described by Daginawala [13]. $1 \mathrm{ml}$ of blood was transferred to each of the 8 previously weighed vials and incubated them $37^{\circ} \mathrm{C}$ for $45 \mathrm{~min}$. After incubation, blood clots remain in the bottom of the vials and the serum was removed from upper portion. Then the weight of the clots containing vials was taken. $100 \mu \mathrm{l}$ of sample extract solutions was taken in four vials (vials $1,2,3,4$ ) and $100 \mu \mathrm{l}$ distilled water was taken in vial two vials (Vial 5,6) and $100 \mu \mathrm{l}$ streptokinase was taken in last two vials (vial 7 and 8). All the vials were incubated for $90 \mathrm{~min}$ at $37^{\circ} \mathrm{C}$ and again the serum was removed upper portion and the clots remained at the bottom. Then the weight of the vials was taken again. After incubation the lysis of the blood clot was calculated by following equation- 
$\%$ of clot lysis $=($ weight of the clot after lysis/weight of the clot before lysis $)$ $\times 100$

\section{Membrane stabilizing potential}

The hypotonic and heat induced membrane stabilizing activity of the extracts was determined on human erythrocytes by using the method of Shahriar [14]. In hypotonic solution- induced hemolysis, the test sample made of stock erythrocyte (RBC) suspension $(30 \mu \mathrm{L})$ with $5 \mathrm{ml}$ of hypotonic solution $(50 \mathrm{mMNaCl})$ in $1 \mathrm{ml}, 10 \mathrm{mM}$ sodium phosphate buffer saline ( $\mathrm{pH}$ 7.4) containing either the seed and stem bark extracts $(1 \mathrm{mg} / \mathrm{ml})$ or acetyl salicylic acid $(0.10 \mathrm{mg} / \mathrm{ml})$. The acetyl salicylic acid was used as a reference standard. The mixtures was incubated for $10 \mathrm{~min}$ at room temperature, centrifuged for $10 \mathrm{~min}$ at $1500 \mathrm{rpm}$ and the absorbance (O.D.) of the supernatant was measured at $540 \mathrm{~nm}$ using UV spectrophotometer. The percentage inhibition of either hemolysis or membrane stabilization was calculated using the following equation

\%inhibition of haemolysis $=100 \times\left\{\left(\mathrm{OD}_{1}-\mathrm{OD}_{2}\right) / \mathrm{OD}_{1}\right\}$

Where,

$\mathrm{OD}_{1}=$ Optical density of hypotonic-buffered saline solution alone (control) and

$\mathrm{OD}_{2}=$ Optical density of test sample in hypotonic solution.

In heat induced hemolysis, $5 \mathrm{ml}$ of the isotonic buffer, containing $0.5 \mathrm{ml}$ of seed and stem bark extracts (dissolved in distilled water) was put into two duplicate sets of falcon tubes. The vehicle, in the same amount was added to another tube as control. Erythrocyte suspension $(30 \mu \mathrm{L})$ was added to each tube \& mixed gently by inversion. One pair of the tubes was incubated at $54{ }^{\circ} \mathrm{C}$ for $20 \mathrm{~min}$ in a water bath. The other pair was maintained at $0-5{ }^{\circ} \mathrm{C}$ in an ice bath. The reaction mixture was centrifuged for $10 \mathrm{~min}$ at $3000 \mathrm{rpm} \&$ the absorbance of the supernatant was measured at $540 \mathrm{~nm}$. The percentage inhibition or acceleration of hemolysis in tests was calculated according to the following equation-

\%Inhiition of haemolysis $=100 \times\left[1-\left(\mathrm{OD}_{2}-\mathrm{OD}_{1} / \mathrm{OD} 3-\mathrm{OD}_{1}\right)\right]$

Where,

$\mathrm{OD}_{1}=$ test sample unheated,

$\mathrm{OD}_{2}=$ test sample heated \&

$\mathrm{OD}_{3}=$ control sample heated

\section{Evaluation of antimicrobial activity}

Disc diffusion method is a classical method used to test antimicrobial susceptibility. This method was first described by Bauer who had attempted the method against a large number of bacteria [15]. In this method, the test substance is soaked in $6 \mathrm{~mm}$ diameter filter paper discs and placed in muellerhinton agar media. The test substance will out of the disc into the media based on the solubility of the substance in the media and size. The area where the concentration of the test substance is sufficient to inhibit bacterial growth, there will be clear zones. By measuring the diameter of the clear zone, it is possible to predict the antibacterial activity of the test substance. The same principle can be applied to the measurement of antifungal activity. Standard disc of Kanamycin antibiotic $(5 \mu \mathrm{g} /$ disc), Fluconazole antifungal discs $(25 \mu \mathrm{g})$, blank discs and solvent discs were used as positive and negative control, respectively. The antimicrobial activity of the test agents was determined by measuring the diameter of zone of inhibition expressed in $\mathrm{mm}$.

\section{Experimental animal}

For the experiment Swiss albino male mice, 4-5 weeks of age, weighing between 25 and $30 \mathrm{~g}$ were collected from ICDDR, B, Mohakhali, Dhaka. Animals were maintained under standard environmental conditions (temperature: $(25.0 \pm 2.0)^{\circ} \mathrm{C}$, relative humidity: (55-65) $\%$ and $12 \mathrm{~h}$ light $/ 12 \mathrm{~h}$ dark cycle) and free access to feed and water. The animals were acclimatized to laboratory condition for 1 week prior to experiments. All protocols for animal experiment were approved by the institutional ethical committee.

\section{Anti-diarrheal activity by castor oil induced method}

The experiment was carried out by the slightly modified procedure previously described by Umer [16]. The anti-diarrheal activity of the methanolic extract of seed and stem bark of Ziziphus mauritiana was evaluated using the method of castor oil induced diarrhea in mice. The animals were divided into control, positive, and test groups containing four mice in each group. Control group received vehicle (plain distilled water) at dose $10 \mathrm{ml} / \mathrm{kg}$ orally. The positive control group received loperamide at the dose of $50 \mathrm{mg} / \mathrm{kg}$ orally. The test group received methanolic extract of seed and stem bark at the doses of $200 \mathrm{mg} / \mathrm{kg}$ and $400 \mathrm{mg} / \mathrm{kg}$ body weight. Each animal was placed in an individual jar of the floor surface was covered with absorbent tissue paper. The floor covering was changed at every hour and their stool counted. After 60 min of administration of test samples the mice of all groups were orally treated with $0.5 \mathrm{ml}$ of castor oil. Then the mice were placed in transparent cages to observe for consistency of fecal matter and frequency of detection for $4 \mathrm{~h}$. The activity was expressed as percent inhibition of diarrhea. 


\section{Peripheral analgesic activity by acetic acid induced writhing test}

The acetic acid writhing test in mice as described by Koster was employed with slight modification [17]. Mice were randomly divided into six groups of four mice in each group. Each group received a particular treatment. The first group was given $10 \mathrm{ml} / \mathrm{kg}$ of $1 \%$ Tween 80 orally and served as control. Group 2 was served as standard where diclofenac sodium has given to mice as dose of $50 \mathrm{mg} / \mathrm{kg}$ of body weight. Groups 3, 4 received 200 $\mathrm{mg} / \mathrm{kg}$ and $400 \mathrm{mg} / \mathrm{kg}$ of body weight of seed extract. Groups 5, 6 received $200 \mathrm{mg} / \mathrm{kg}$ and $400 \mathrm{mg} / \mathrm{kg}$ of body weight of stem bark extract. Thirty minutes later each mouse was injected intra peritoneally with $0.7 \%$ acetic acid at doses of $10 \mathrm{ml} / \mathrm{kg}$ of body weight. Full writhing was not always completed by the mice. Accordingly, two half writhing were considered as one full writhing. The number of writhing responses was recorded for each mouse during a subsequent $5 \mathrm{~min}$ period after $15 \mathrm{~min}$ intra peritoneal administration of acetic acid and the mean abdominal writhing for the each group was obtained and recorded.

\section{Anti-diabetic activity}

Mice were kept fasting overnight with free access to water. Before administration of drug and extract solutions fasting blood glucose levels were estimated by glucose oxidase method [18, 19]. Twenty four fasted mice were divided into 6 groups had 4 mice in each group. Group I served as control and received only Tween- 80 (a suspending agent) and DMSO mixed with normal saline water. Group II was administered glibenclamide orally at dose of $5 \mathrm{mg} / \mathrm{kg}$ body weight. The crude methanolic extract as a dose of $200 \mathrm{mg} / \mathrm{kg}$ body weight and $400 \mathrm{mg} / \mathrm{kg}$ body weight as fine aqueous suspension were administered orally to group III to group VI. After 60 min of administration of test samples, the mice of all groups were orally treated with $20 \mathrm{mg} / \mathrm{ml}$ glucose solution $(200 \mathrm{mg} / \mathrm{kg}$ body wt.). Blood samples were collected from tail vein just prior to glucose administration and at 1,2 and $3 \mathrm{~h}$ after glucose loading. Blood glucose level of the experimental animals was measured by using a glucometer and glucose-oxidase- peroxidase reactive strips.

\section{Acute toxicity study}

Acute toxicity describes the adverse effects of a substance which results either from a single exposure or multiple exposures in a short period of time, usually less than $24 \mathrm{~h}$. Acute toxicity of seed and stem bark extract of Ziziphus mauritiana was determined as described by Walum [20]. Mice were randomly divided into eleven groups of four mice in each group. Each group received a particular treatment. Group I served as control and received only $10 \mathrm{ml} / \mathrm{kg}$ normal saline water. Group II to VI served as seed extract and group VII to XI served as stem bark extract and received single oral dose each of $500 \mathrm{mg} / \mathrm{kg}, 1000 \mathrm{mg} / \mathrm{kg}, 1500 \mathrm{mg} / \mathrm{kg}, 2000 \mathrm{mg} / \mathrm{kg}$ and $4000 \mathrm{mg} / \mathrm{kg}$ body weight respectively. Animals were observed for behavior and mortality rate.

\section{Statistical analysis}

Data was expressed as Mean \pm SEM (Standard error of Mean). The results were analyzed statistically by using Microsoft Excel 2010. T-test of two equal variance were done and results below $* p<0.05, * p<0.01$ and $* * *<<$ 0.001 are considered statistically significant. $\mathrm{IC}_{50}$ values for scavenging of free radicals, $\mathrm{LC}_{50}$ and $\mathrm{LC}_{90}$ for cytotoxicity were calculated from the dose response curve.

\section{Results}

Ethno-medicinal survey of Ziziphus mauritiana

All the kavirajes interviewed were male, secondary level educated and professional (full time) healer of Gaibandha district of Bangladesh. All of them were belongs to the age in between 40 and 50 years. Ziziphus mauritiana is found almost all over the country and considered as an effective herbal remedy. According to this study, it was found that the various parts of this plant are used in the treatment of in fever, indigestion, liver disease, diarrhea, wound healing and jaundice (Table 1).

\section{Phytochemical screening}

The preliminary phytochemical screening of selected parts of Ziziphus mauritiana confirmed the presence of some secondary metabolites like carbohydrates, glycosides, steroids, flavonoids, alkaloids summarized in Table 2.

\section{Antioxidant properties \\ Determination of total phenol content}

The stem bark extract had highest amount of total phenol content $(69.591 \pm 0.92 \mathrm{mg} / \mathrm{g}$ of GAE) than seed extract $(62.475 \pm 0.39 \mathrm{mg} / \mathrm{g}$ GAE), which was calculated from the regression equation of the calibration curve ( $y=0.0069 x-0.0341$ and $R^{2}=0.9961$ ) of reference standard gallic acid (Table 3 ).

\section{Determination of flavonoid content}

The total flavonoid content of both extracts was lower than the total phenolic content, which is often the case for most plants. Quercetin was used as a reference standard to estimate total flavonoid content of the plant extracts. Flavonoid content of seed and stem bark extracts were $15.500 \pm 0.50 \mathrm{mg} / \mathrm{g}$ and $33.000 \pm 2.00 \mathrm{mg} / \mathrm{g}$ of quercetin equivalent which was estimated from the regression equation $\left(y=0.0002 x-0.0002\right.$ and $\left.R^{2}=0.9965\right)$ of quercetin (Table 3 ). 
Table 1 Traditional usage of Ziziphus mauritiana

\begin{tabular}{lll}
\hline Plant Parts & Disease & Method of Use \\
\hline Fruits & Improved the digestion and liver function & Juice of fruit and fresh fruit \\
& Fever & Prepared juice combined with Chalta (Dellenia indica) by mixing with sugar \\
& Wound healing & Dried ripe fruit given as orally \\
Leaves & Liver function and jaundice & Prepared juice by mixing with sugar \\
Barks & Wound healing & Topical application of paste \\
Roots & Wound healing & Topical application of paste \\
Seeds & Not Used & \\
Flowers & Not Used & \\
\hline
\end{tabular}

\section{Determination of total antioxidant capacity}

The total antioxidant capacities of the seed and stem bark extracts of were determined from the calibration curve $\left(y=0.0008 x-0.0002\right.$ and $\left.R^{2}=0.9906\right)$ established by reference standard ascorbic acid. Total antioxidant capacity of seed and stem bark extract were $13.675 \pm$ $0.87 \mathrm{mg} / \mathrm{g}$ and $39.000 \pm 0.87 \mathrm{mg} / \mathrm{g}$ of ascorbic acid equivalent (Table 3 ).

\section{DPPH free radical scavenging assay}

The antioxidant activity of the extractives of BAU Kul was evaluated by the widely used and most reliable DPPH radical scavenging assay method. This antioxidant assay is based on the ability of the extractives to scavenge the stable DPPH radical that contains an odd electron. The calculated $\mathrm{IC}_{50}$ value for the seed and stem bark extract were $4.53 \mu \mathrm{g} / \mathrm{ml}(\mathrm{y}=13.814 \mathrm{x}-12.615$ and $\left.\mathrm{R}^{2}=0.9811\right)$ and $4.13 \mu \mathrm{g} / \mathrm{ml}(\mathrm{y}=14.244 \mathrm{x}-8.7692$ and $\left.\mathrm{R}^{2}=0.9606\right)$ compared with the reference standard ascorbic acid, which had $\mathrm{IC}_{50}$ value of $3.43 \mu \mathrm{g} / \mathrm{ml}(\mathrm{y}=$ $16.515 x-6.5688$ and $R^{2}=0.9374$ ) (Fig. 1 and Table 4).

Table 2 Phytochemical screening of Ziziphus mauritiana extractives

\begin{tabular}{|c|c|c|}
\hline Phytochemical Tests & Seed & Stem Bark \\
\hline Carbohydrates & ++ & +++ \\
\hline Glycosides & +++ & ++ \\
\hline Glucosides & - & ++ \\
\hline Saponins & + & +++ \\
\hline Steroids & +++ & ++ \\
\hline Tannins & - & + \\
\hline Flavonoids & + & + \\
\hline \multicolumn{3}{|l|}{ Alkaloids } \\
\hline Hager's reagent & ++ & + \\
\hline Wagner's reagent & + & ++ \\
\hline Dragendroff's reagent & + & + \\
\hline
\end{tabular}

[Note, $-=$ Not present,$+=$ Present in mild amount,$++=$ Present in moderate amount, $+++=$ Present in large amount]

\section{Nitric oxide (NO) scavenging assay}

Free radical scavenging activity of Ziziphus mauritiana extracts was also measured by using nitric oxide method. The stem bark extract had higher $\mathrm{IC}_{50}$ of $5.47 \mu \mathrm{g} / \mathrm{ml}$ $\left(y=11.66 x-13.725\right.$ and $\left.R^{2}=0.9949\right)$ than seed extracts $\left(5.92 \mu \mathrm{g} / \mathrm{ml}, \mathrm{y}=10.903 \mathrm{x}-14.51\right.$ and $\left.\mathrm{R}^{2}=0.9854\right)$ compared against the standard ascorbic acid $(4.77 \mu \mathrm{g} / \mathrm{ml}, \mathrm{y}=$ 13.256x - 13.186 and $R^{2}=0.996$ ), (Fig. 2 and Table 4).

\section{Cytotoxicity}

In brine shrimp lethality bioassay, the crude extracts were screened for probable cytotoxic activity. The concentration at which $50 \%$ and $90 \%$ mortality of brine shrimp nauplii occurred were determined. In this study, seed extract was found most cytotoxic as evidenced from its $\mathrm{LC}_{50}$ and $\mathrm{LC}_{90}$ values (Calculated from regression equation, $\mathrm{y}=39.29 \mathrm{x}-7.6485$ and $\mathrm{R}^{2}=0.9633$ ) against brine shrimp $\left(\mathrm{LC}_{50}=1.46 \mu \mathrm{g} / \mathrm{ml}\right.$ and $\left.\mathrm{LC}_{90}=2.48 \mu \mathrm{g} / \mathrm{ml}\right)$ and compared against reference standard cytotoxic drug vincristine sulphate (Table 4).

\section{Thrombolytic activity}

Several thrombolytic drugs obtained from various sources are used for the treatment of thrombosis. Thrombolytic agents are used to disrupt already formed blood clots in clinical settings where ischemia may be fatal. As a part of discovery of cardio protective drugs from natural resources the extractives of $Z$. mauritiana were assessed for thrombolytic activity and the results are presented in Table 4.

\section{Membrane stabilizing potential}

The different parts of crude extracts of $Z$. mauritiana protected the haemolysis of RBC, induced by hypnotic solution and heat as compared to the standard acetylsalicylic acid (ASA). In hypotonic solution induced and heat induced hemolysis, ASA inhibited the haemolysis of RBC $64.24 \pm 0.44 \%$ and $67.59 \pm 1.462 \%$, seed inhibited $25.00 \pm 1.56 \%$ and $34.79 \pm 2.553 \%$, stem bark inhibited $41.88 \pm 1.58 \%$ and $46.0 \pm 2.951 \%$ respectively, summarized in Table 4. 
Table 3 Total phenol, flavonoid and antioxidant capacity of seed and stem bark extract of Ziziphus mauritiana

\begin{tabular}{llll}
\hline Extracts & Total Phenol Content, $\mathbf{~ m g / g ~ G A E}$ & Total Falvonoid Content, $\mathbf{~ m g / g ~ Q E}$ & Total Antioxidant Capacity, mg/g AAE \\
\hline Seed & $62.475 \pm 0.39^{\mathrm{a}, \mathrm{b}}$ & $15.500 \pm 0.50^{\mathrm{a}}$ & $13.675 \pm 0.87^{\mathrm{b}}$ \\
Stem Bark & $69.591 \pm 0.92^{\mathrm{a}} \mathrm{b}$ & $33.000 \pm 2.00^{\mathrm{a}}$ & $39.000 \pm 0.87^{\mathrm{b}}$
\end{tabular}

[Values are represented as mean + SEM, t-test of two equal variance was done to analyze the data set. Values in the same column with different superscripts are significantly different from another, $\left.p^{<} 0.05\right]$

\section{Evaluation of antimicrobial activity}

In this present study, two gram positive, two gram negative and a fungus microorganism were evaluated for anti-microbial activities and only the stem bark extract showed antibacterial activity (Fig. 3), but lacked of antifungal activity at $400 \mu \mathrm{g} / \mathrm{disk}$ (Table 5).

\section{Anti-diarrheal activity by castor oil induced method} The effect of the methanolic extract of $Z$. mauritiana on castor oil induced diarrhoea in mice showed a dose dependent decrease in the number of defected pellets. The seed extract at a dose $200 \mathrm{mg} / \mathrm{kg}$ and $400 \mathrm{mg} / \mathrm{kg}$ reduced defected pellet by $37.84 \%$ and $62.16 \%$ whereas the stem bark extract showed $54.05 \%$ and $75.68 \%$ inhibition of defection respectively, shown in Fig. 4.

\section{Peripheral analgesic activity by acetic acid induced writhing test}

In the analgesic activity performed using acetic acidinduced writhing model in mice, the seed extract produced $45.10 \%$ and $64.71 \%$ writhing inhibition at the doses of $200 \mathrm{mg} / \mathrm{kg}$ and $400 \mathrm{mg} / \mathrm{kg}$ body weight respectively. At same dose, the others sample methanol stem bark extract inhibited the writhing $49.02 \%$ and $68.63 \%$ respectively, shown in the Fig. 5.

\section{Anti-diabetic activity}

The hypoglycemic activity is an important parameter to evaluate anti-diabetic activity and it was showed by dose dependent manner. In this study, upon increment of the dose, the plant extracts showed increased level of hypoglycemic activity. According to this study, stem bark extract showed higher \% reduction of blood glucose level than seed extract at both dose (Fig. 6).

\section{Acute toxicity study}

Safety of plant extract is evaluated mostly by acute oral toxicity study. Among the 11 mice group, no death or toxic reaction was observed in mice during the test period. This indicated the absence of any toxic material in the extracts of $Z$. mauritiana. The seed and stem bark plant extract of this plant was found safe up to $4000 \mathrm{mg}$ / $\mathrm{kg}$ body weight dose.

\section{Discussion}

Herbal medicines are the staple of medical treatment in many developing countries and used for virtually all minor ailments. Individual herbal medicines in developing regions vary considerably, healers in each region have learned over centuries which local herbs have medicinal worth [21]. Traditional botanical knowledge and experience can be useful not only for the biologists, but also these are equally relevant for anthropologist,

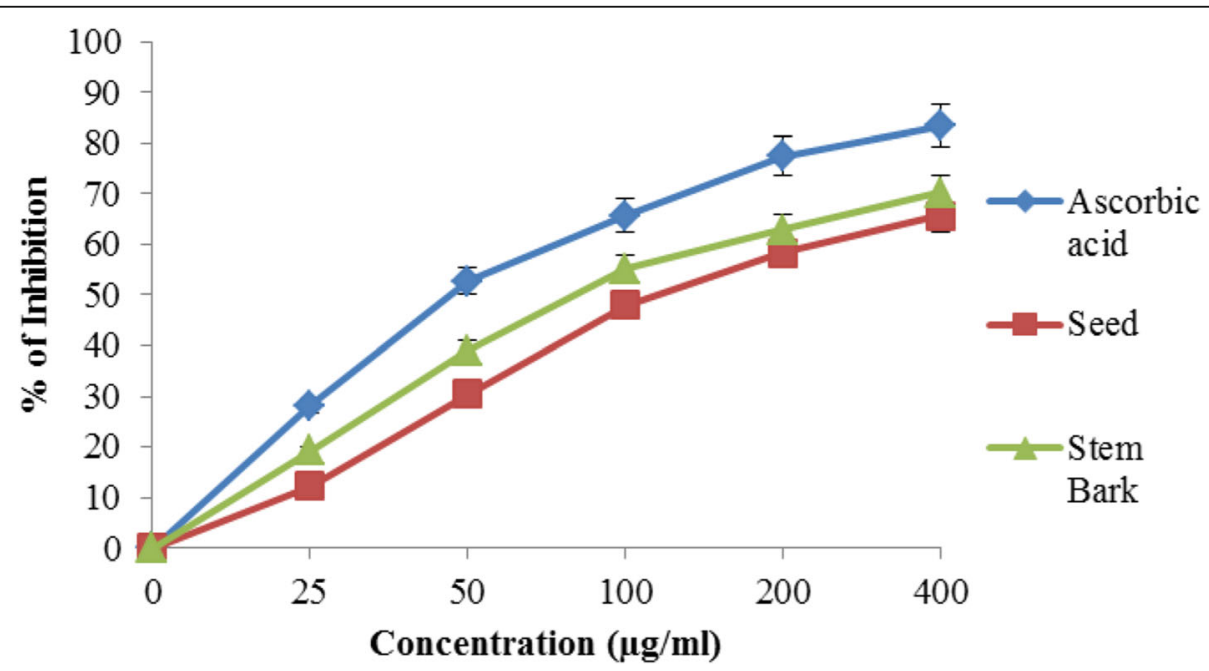

Fig. 1 Curve of DPPH scavenging of Z. mauritiana at different concentrations 
Table $4 \mathrm{IC}_{50}$ values of DPPH, NO, $\mathrm{LC}_{50}, \mathrm{LC}_{90}$ values of brine shrimp lethality bioassays, \% of clot lysis and \% inhibition of hypotonic solution and heat induce hemolysis of the different extractives and standard

\begin{tabular}{|c|c|c|c|c|c|c|c|}
\hline \multirow[t]{2}{*}{ Extracts } & \multicolumn{2}{|c|}{$\begin{array}{l}\text { Scavenging capacity assay, } \\
\mathrm{IC}_{50}(\mu \mathrm{g} / \mathrm{ml})\end{array}$} & \multicolumn{2}{|c|}{$\begin{array}{l}\text { Brine shrimp lethality } \\
\text { bioassay }(\mu \mathrm{g} / \mathrm{ml})\end{array}$} & \multirow{2}{*}{$\begin{array}{l}\text { Thrombolytic activity } \\
\% \text { of clot lysis }\end{array}$} & \multicolumn{2}{|c|}{$\begin{array}{l}\% \text { Inhibition of hemolysis } \pm \text { SEM (membrane } \\
\text { stabilizing potential) }\end{array}$} \\
\hline & DPPH & NO & $\mathrm{LC}_{50}$ & $\mathrm{LC}_{90}$ & & Hypotonic Solution & Heat Induce \\
\hline SE & $4.53^{\mathrm{a}, \mathrm{b}}$ & $5.92^{b}$ & $1.46^{\mathrm{a}}$ & 2.48 & 24.95 & $25.00 \pm 1.56$ & $34.79 \pm 2.55$ \\
\hline SBE & $4.13^{\mathrm{a}, \mathrm{b}}$ & $5.47^{b}$ & $1.92^{\mathrm{a}}$ & 3.25 & 34.65 & $41.88 \pm 1.58$ & $46.03 \pm 2.95$ \\
\hline AA & 3.43 & 4.77 & - & - & - & - & - \\
\hline VS & - & - & 0.39 & 1.12 & - & - & - \\
\hline SK & - & - & - & - & 66.38 & - & - \\
\hline $\mathrm{DL}$ & - & - & - & - & $6.91 \%$ & - & - \\
\hline ASA & - & - & - & - & - & $64.24 \pm 0.44$ & $67.59 \pm 1.46$ \\
\hline
\end{tabular}

[SE Seed Extract, SBE Stem Bark Extract, AA Ascorbic Acid, VS Vincristine Sulphate, SK Streptokinase, DL Distilled Water, ASA Acetyl Salicylic Acid. Data was expressed as Mean \pm SEM (Standard error of Mean). t-test of two equal variance was done to analyze the data set. Values in the same column with different superscripts are significantly different from another, $\left.p^{<} 0.05\right]$

archaeologists, environmental scientists, foresters, sociologists, literatures, geographers, pharmacists and many others who take interests bioresources [22]. The fresh fruit and juice of fruit of Ziziphus mauritiana improved the digestion and liver disease. Sometime the combination fruit of BAU Kul (Ziziphus mauritiana) and Chalta (Dellenia indica) are given in treatment of fever prepared by juice mixing with sugar. Dried ripe fruit given as orally in the treatment of wound healing. The paste of bark and root also effective on wound healing and in the treatment of diarrhea, dried bark and young roots are blended and combined/single, prepared juice mixed with sugar and water administered orally. It is reported that the juice of leaves improves liver function and jaundice. There were no use found of flower and seed. Due to a lack of research, little is known about the safety of consuming any type of Ziziphus mauritiana plant in dietary supplement form, but in our present study, there were no side effect reported by the folk medicine practitioners. Seed contained carbohydrate, glucoside, saponin, steroid, flavonoid, alkaloid but it also indicates the absence of glycoside and tannin. The stem bark showed the presence of all secondary metabolites which are carbohydrate, glycoside, glucoside, saponin, steroid, tannin, flavonoid and alkaloid. Phenolics are important constituents that contribute to the functional quality, color and flavor of plants and they have significant roles both as singlet oxygen quenchers and free radical scavengers that help to minimize molecular damage [23]. Both extract showed higher phenolic content, moderate flavonoid content and antioxidant capacity. The antioxidant activity results showed increased activity by dose

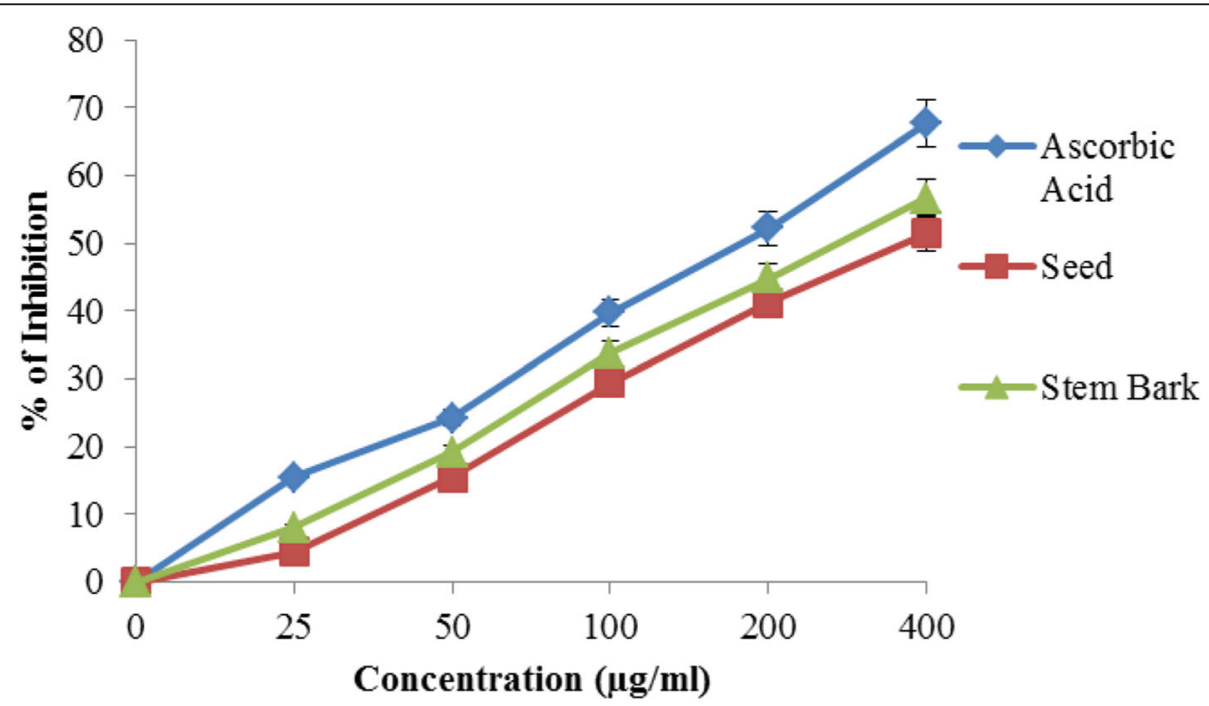

Fig. 2 Curve of Nitric Oxide (NO) scavenging of Z. mauritiana at different concentrations 


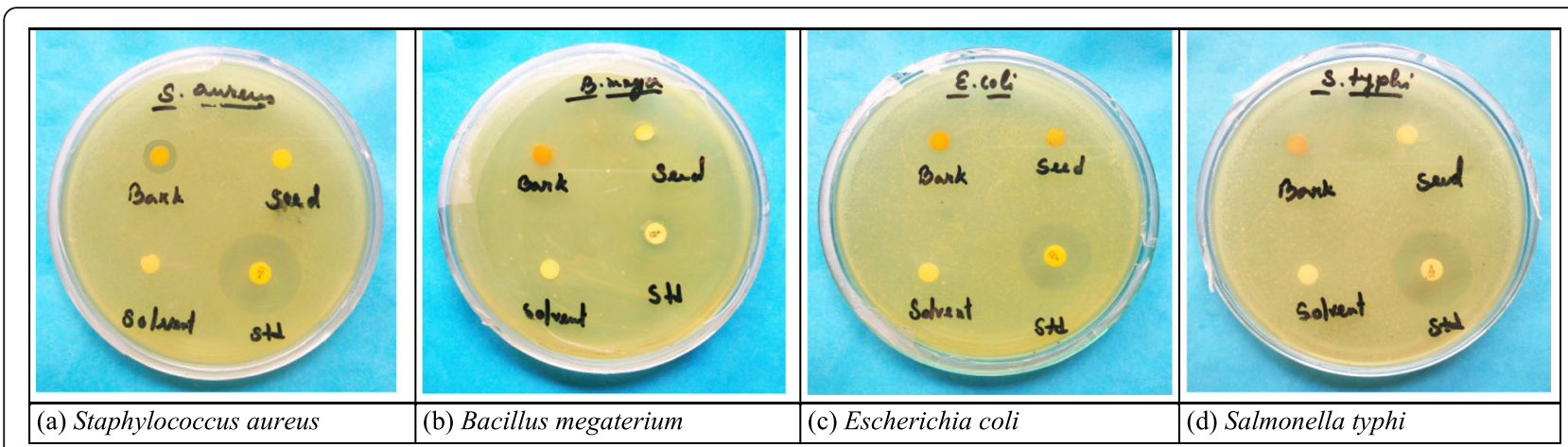

Fig. 3 Zone of inhibition of Ziziphus mauritiana extracts and standard in selected microorganism

dependent manner. Both extracts showed excellent free radicals scavenging potential. In this study, stem bark extract was more potential antioxidant potential than seed extract. Both extracts showed very good cytotoxic activity compared to the standard vincristine sulphate. The lower the $\mathrm{LC}_{50}$ and $\mathrm{LC}_{90}$ values of a sample indicate the higher bioactivity. A similar result was found in ethanol extracts of leaves of this plant [24].

In present study, methanolic seed and stem bark extracts of $Z$. mauritiana were evaluated for possible thrombolytic potential. The thrombolytic activities of the extracts were evaluated against reference standard streptokinase. $100 \mu \mathrm{l}$ streptokinase (SK) as a positive control $(30,000 \mathrm{IU})$ showed $66.38 \%$ lysis of clot on the other hand sterile distilled water was treated as negative control which exhibited a negligible percentage of lysis of clot $6.91 \%$. In vitro thrombolytic activity study revealed that seed and stem bark extract exhibited 24.95\% and $34.65 \%$ clot lysis respectively. This study revealed that the stem bark extract of $Z$. mauritiana exhibited highest thrombolytic activity. The seed and stem bark extracts had lower clot lysis potential than leaves extract [25]. Inflammation is due to release of lysosomal constituent's that also causes cell death. Rupturing of lysosomal membrane releases lysosomal constituents and the

Table 5 Antimicrobial activity of Z. mauritiana extractives

\begin{tabular}{lllll}
\hline Test Microorganisms & \multicolumn{4}{l}{ Zone of inhibitions $(\mathrm{mm})$} \\
\cline { 2 - 5 } & Methanol & Seed & Stem Bark & Standard \\
\hline Gram positive bacteria & & & & Kanamycin \\
Staphylococcus aureus & 0 & 0 & 14 & 27 \\
Bacillus megaterium & 0 & 0 & 12 & 25 \\
Gram negative bacteria & & & & \\
Escherichia coli & 0 & 0 & 10 & 24 \\
Salmonella typhi & 0 & 0 & 10 & 20 \\
Fungi & & & & Fluconazole \\
Aspergillus niger & 0 & 0 & 0 & 20 \\
\hline
\end{tabular}

stabilization of lysosomal membrane inhibits the release of lysosomal constituents [26]. Thus. Membrane stabilizing activity is related to anti-inflamatory activities. Inhibition of hypotonic solution and heat induced erythrocyte membrane lysis can be taken for the in-vitro determination of anti-inflammatory activity of drugs or plant extracts [27]. Both seed and stem bark extracts showed potential anti-inflamatory activity. A similar data were found of different extractives of leaves of $Z$. mauritiana on hypotonic solution and heat induces hemolysis of erythrocyte membrane [26]. A human pathogen is a kind of disease causing microorganism which induces infection by invasion and multiplication within human being. Sometimes, one's immune system alone cannot fight against these virulent pathogens when an individual exposed to them. In that case antimicrobial agents as therapeutics are used. Among all the microbes, bacteria is responsible for terrible infectious diseases in humans. Microorganism grows very fast by multiplication and induces infection through endotoxins and exotoxins [28]. To kill bacteria, there huge numbers of antibiotics are available. But unfortunately, these pathogens can easily be mutated and become less susceptible or resistant towards latest generation antibiotics by changing their genetic information very quickly. Whereas the side effects of such antibiotics can cause serious organ damage like liver and kidney [29]. As a result, in critical clinical situations, it is seen that patients are dying in infectious diseases due to the inactivity of antibiotics. In the present study, among the five tested organisms, the stem bark extract of Ziziphus mauritiana resulted in variable zone of inhibitions but seed extract showed resistance to all tested microorganism at concentration $400 \mu \mathrm{g} / \mathrm{ml}$. Stem bark extract displayed its effectiveness against gram-positive strain Staphylococcus aureus, Bacillus megaterium and gram negative strain Escherichia coli, Salmonella typhi to a potential extent compared with kanamycin shown in Table 3. A similar activity was found for different parts of Ziziphus mauritiana $[3,24,30]$. 




Fig. $4 \%$ Inhibition of defecated pellets of plant extract and standard. [t-test of two equal variance were done to compare the significance of the result and ${ }^{*} p<0.05,{ }^{* *} p<0.01$ and ${ }^{* *} p<0.001$ are considered statistically significant]

In anti diarrheal study, significant reduction of defected pellet was found compared to the standard loperamide. Stem bark extract showed higher activity than seed extract at same dose. At a dose $400 \mathrm{mg} / \mathrm{kg}$ body weight both stem bark and seed extract exhibited highly reduction of the defected pellet compared with the standard loperamide at dose $50 \mathrm{mg} / \mathrm{kg}$ body weight.
Similar result was also reported previously of different part of this plant [31,32]. The diarrhea inducing properties is as a result of ricinoleic acid; a castor oil active metabolite, which is liberated by the action of lipases in the upper part of the small intestine. Ricinoleic acid exerts its effect by production of local irritation and inflammation of the intestinal mucosa, causing the release of

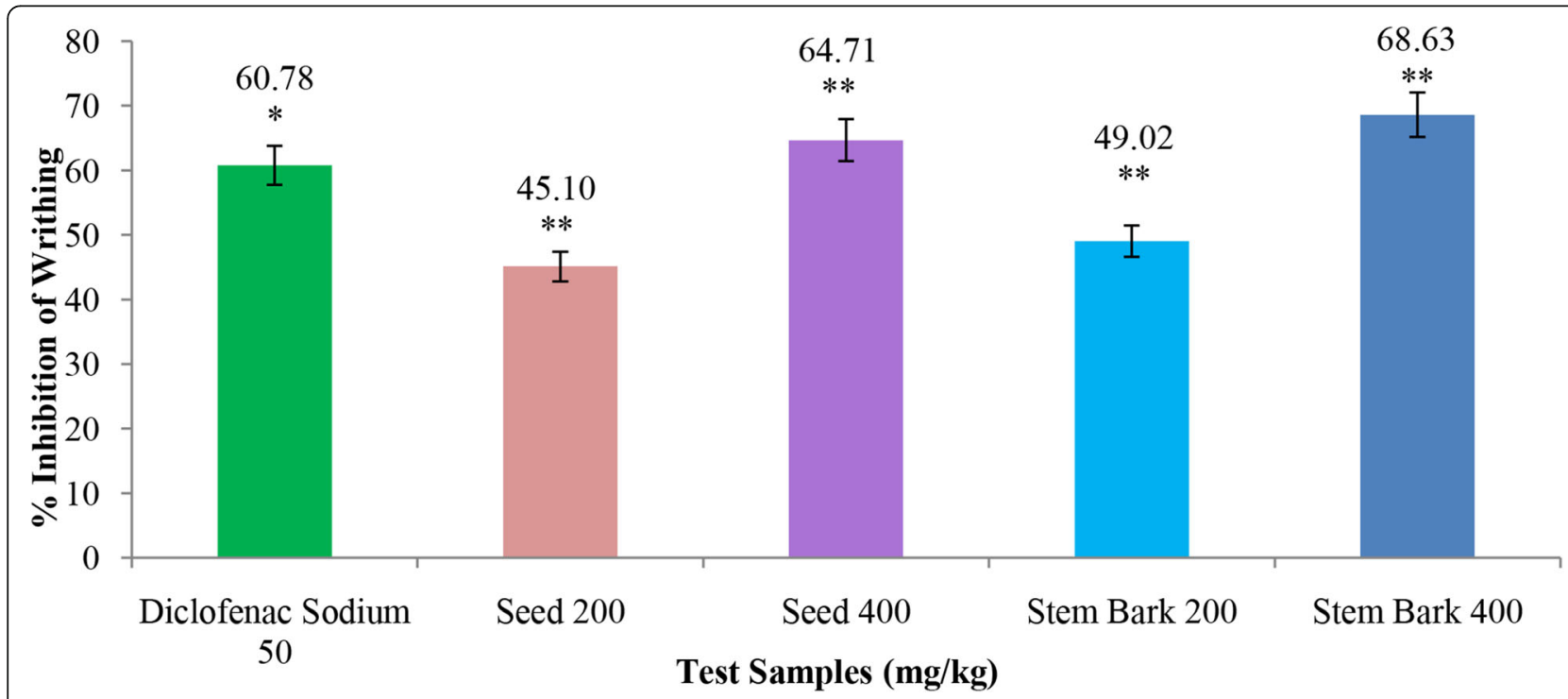

Fig. $5 \%$ Inhibition of writhing of plant extract and standard. Page 17 [t-test of two equal variance were done to compare the significance of the result and ${ }^{*} p<0.05,{ }^{* *} p<0.01$ and ${ }^{* * *} p<0.001$ are considered statistically significant] 


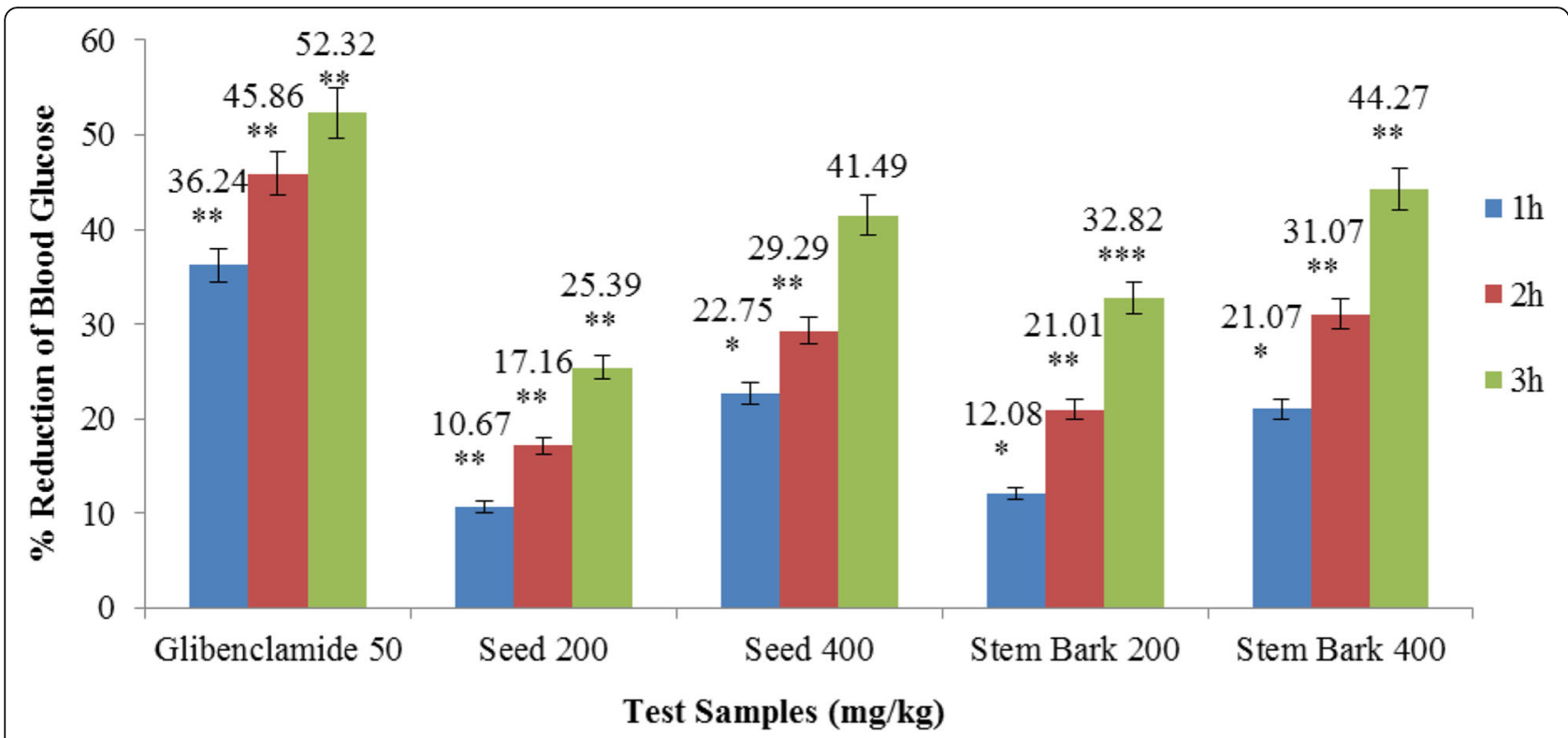

Fig. $6 \%$ Reduction of blood glucose level in different hour. [t-test of two equal variance were done to compare the significance of the result and ${ }^{*} p<0.05,{ }^{* *} p<0.01$ and ${ }^{* * *} p<0.001$ are considered statistically significant]

prostaglandins that eventually increases gastrointestinal motility and net secretion of water and electrolytes [33]. Thus, the anti diarrheal effect of the seed and stem bark could be attributed to inhibition of castor oil-induced prostaglandin synthesis. The anti-diarrheal activity might also be due to inhibition of active secretion of ricinoleic acid, resulting in the activation of $\mathrm{Na}^{+}, \mathrm{K}^{+}$ATPase activity that promotes absorption of $\mathrm{Na}^{+}$and $\mathrm{K}^{+}$in the intestinal mucosa. This effect could probably be linked to the presence of terpenoids, tannins and flavonoids in the seed and bark extract, which are shown to promote colonic absorption of water and electrolytes [34]. The acetic acid induced abdominal constriction test is used frequently for peripherally acting drugs. The pain induction occurs by liberating endogenous substances as well as some other pain mediators such as arachidonic acid metabolites via cyclooxygenases, such as prostaglandins [35]. The stem bark extract showed more significant analgesic activity than seed extract. At the dose of $400 \mathrm{mg} /$ $\mathrm{kg}$ body weight, the both extract seed and stem bark showed that higher writhing inhibition than the standard diclofenac sodium at the dose of $50 \mathrm{mg} / \mathrm{kg}$ body weight. In this study, the positive standard diclofenac sodium inhibited about $60.78 \%$ at the dose of $50 \mathrm{mg} / \mathrm{kg}$ body weight. Similar activity is found in previous study of different parts of this plant [36, 37]. At higher dose $(400$ $\mathrm{mg} / \mathrm{kg}$ ), for both extracts, \% reduction of blood glucose level almost similar to the standard drug glibenclamide at a dose $5 \mathrm{mg} / \mathrm{kg}$ body weight. The similar hypoglycemic activity was found in previous study of different parts of this plant. The fruit extracts of Ziziphus mauritiana was found effective in reducing both hyperlipidemia and hypoglycaemia accompanying diabetes on alloxan induced diabetic rats. The most effective dose was $400 \mathrm{mg} / \mathrm{kg}$ body weight [38]. The aqueous extract and the non-polysaccharide fraction of the aqueous extract were found to exhibit significant antihyperglycemic and hypoglycemic activities. The petroleum ether extract was found to exhibit only an anti hyperglycemic effect [39]. Another study showed seed extract alone or in combination with glyburide reduced the blood glucose level in all the alloxan diabetic mice after acute and subacute (28 days) administration [40]. Drug safety is one of the important topics in daily medical practice. In this study, no mortality showed even at a maximum dose up to $4000 \mathrm{mg} / \mathrm{kg}$ body weight for both extracts. This observation is agreed with who assessed acute and sub-acute toxicity of hydro-alcoholic fruit extracts of this plant using higher dose $5000 \mathrm{mg} / \mathrm{kg}$ and they reported no behavioural changes and no mortality was observed in rats [38]. There are rare reports on chemical composition on the different parts of $Z$. mauritiana. Ashraf et al., investigated the chemical composition of $Z$. mauritiana leave extracts by GC-MS analysis and found methyl stearate and $\alpha$-linolenic acid as the major components in methanol and hexane extracts. They also confirmed the presence of palmitic acid, phytol methanol, hexane and chloroform extracts of the leaves of Z. mauritiana [41]. Extensive analysis about different phyto-constituents in different parts of $Z$. mauritiana along with their pharmacological properties is highly required. 


\section{Conclusion}

The presence of different phytochemical may be responsible for in-vitro and in-vivo pharmacological properties of BAU Kul. Further investigations are in progress to identify the active constituents responsible for pharmacological activity of Ziziphus mauritiana. In this present study, the data was satisfactory. The difference of pharmacological activity of BAU Kul ( $Z$. mauritiana) may be varying with other $Z$. mauritiana due to genetic variations. In ethnobotanical survey of this study, the data were collected only Gaibandha district in Bangladesh. These data do not include the area of all over the country; therefore regional variation may occur. However, more detailed phytochemical analysis will be necessary to isolate and characterize the active compounds responsible for the pharmacological activities as well as to understand the exact mechanisms of action of their underlying pharmacological activities.

\section{Acknowledgements}

Authors are thankful to Department of Pharmacy, University of Asia Pacific Dhaka, Bangladesh for providing necessary laboratory support and ICDDR'B for their co-operation of providing laboratory animals and their guidance of laboratory animal handling. Authors are also thankful to Al Asma Hawa, for her assistance in laboratory work.

\section{Authors' contributions}

Authors Md. Khokon Miah Akanda and A. H. M. Nazmul Hasan were involved in the laboratory work. Author A.H.M. Nazmul Hasan designed this study and acted as a supervisor of this study. The author(s) read and approved the final manuscript.

\section{Funding}

The authors received no external funding for this research.

\section{Availability of data and materials}

All the data are preserved by the authors and ready to provide at any stage if any question arise.

\section{Ethics approval and consent to participate}

This study was approved in a meeting of Committee for Advanced Studies followed by Ethical Review Committee dated on: 07 March, 2019 (Ref: UAP/ Pharm_CAS-ETA: 07 032019) of the Department of Pharmacy, University of Asia Pacific, further reviewed by ICDDR'B, Dhaka (International Center for Diarrhoeal Disease Research, Bangladesh) prior to the supply of laboratory animals (Swiss albino mice). Laboratory animals were maintained according to standard protocol (Guide for the Care and Use of Laboratory Animals, 8th Edition, National research Council, Washington DC, USA). Written informed consent was obtained from the volunteers from whom blood samples were withdrawn. Blood pressure was measured and history of taking any medications like antiplatelet/corticosteroid were taken and excluded if anyone had history of this.

\section{Consent for publication}

All the authors reviewed the manuscript and provide consent for publication.

\section{Competing interests}

The authors declare that they have no competing interest.

Received: 14 May 2020 Accepted: 30 December 2020

Published online: 16 January 2021

\section{References}

1. Parvez M. Pharmacological activities of mango (Mangifera indica): a review. J Pharmacogn Phytochem. 2016;5(3):01-7.
2. Biswas MMH, Ahmed MLJ, Uddin MB. Development of preservation by processing technologies of BAU kul. J Bangladesh Agric Univ. 2014;12(1): 143-52.

3. Tanvir EM, Afroz R, Karim N, Mttalib A, Hossain I, Islam A, et al. Antioxidant and antibacterial activities of methanolic extract of BAU kul (Ziziphus mauritiana), an improved variety of fruit from Bangladesh. J Food Biochem. 2015;39(2):139-47. https://doi.org/10.1111/jfbc.12109.

4. Parvez M, Akanda KM, Karim R, Mehjabin S, Mou SM, Mosaddik A, et al. Comparative phytochemical screening and antimicrobial evaluation of different varieties of banana (Musa sapientum). Int J Innov Pharm Sci Res. 2016:4(4):372-83.

5. Tiwari P, Kumar B, Kaur M, Kaur G, Kaur H. Phytochemical screening and extraction: a review. Internationale Pharmaceutica Sciencia. 2011:1:103-4.

6. Trease GE, Evans WC. Pharmacognosy. 13th ed. London: ELBS/Bailliere Tindall; 1989. p. 345-3466. 535-536, 772-7703.

7. Stanojevic L, Stankovic M, Nikolic V, Nikolic L, Ristic D, Tumbas V, et al. Antioxidant activity and total phenolic and flavonoid contents of Hieracium pilosella L. extracts. Sensors (Basel). 2009;9(7):5702-14. https://doi.org/10. 3390/s90705702.

8. Bao JY, Cai M, Sun G. Anthocyanins, flavonoid and free radical scavenging activity of chines baybery (Myrial rubia) extracts and their colour properties and stability. J Agric Food Chem. 2005;53:2327-32.

9. Prieto P, Pineda M, Aguilar M. Spectrophotometric quantitation of antioxidant capacity through the formation of a phosphomolybdenum complex: specific application to the determination of vitamin E. Anal Biochem. 1999;269:337-41.

10. Braca A, Tommasi ND, Bari LD, Pizza C, Politi M, Morelli I. Antioxidant principles from Bauhinia tarapotensis. J Nat Prod. 2001;64(7):892-5. https:// doi.org/10.1021/np0100845.

11. Sreejayan S, Rao MNA. Nitric oxide scavenging by curcuminoids. J Pharm Pharmacol. 1997;49(1):105-7. https://doi.org/10.1111/j.2042-7158.1997. tb06761.x

12. Meyer BN, Ferrigni NR, Putnam JE, Jacobsen JB, Nicholsand DE, Mclaughlin $J$. Brine shrimp: a convenient general bioassay for active plant constituents. Planta Med. 1982;45(5):31-4. https://doi.org/10.1055/s-2007-971236.

13. Daginawala HF, Prasad S, Kashyap RS, Deopujari JW, Purothi HJ, Taori GM. Development of an in vitro model to study clot lysis activity of thrombolytic drugs. Thromb J. 2006:4:1-14. https://doi.org/10.1186/1477-9560-4-14.

14. Shahriar M, Mannan M, Akhter R, Bhuiyan MA. Evaluation of in vitro membrane stabilizing activity and thrombolytic activity of Averrhoa bilimbi leaf extracts. Int J Pharm. 2015;5(2):357-60.

15. Bauer AW, Kirby WM, Sherris JC, Turck M. Antibiotic susceptibility testing by a standardized single disk method. Am J Clin Pathol. 1966;45(4):493-6 PMID: 5325707.

16. Umer S, Tekewe A, Kebede N. Antidiarrhoeal and antimicrobial activity of Calpurnia aurea leaf extract. BMC Complement Altern Med. 2013;13:1-21.

17. Koster $\mathrm{R}$, Anderson M, DeBeer E. Acetic acid for analgesic screening. Fed Proc. 1959;18:412-8.

18. Barham D, Trinder P. An improved color reagent for the determination of blood glucose by oxidase system. Analyst. 1972;97:142-5.

19. Ozbek H, Ceylan E, Kara M, Ozgokee F, Koyuncu M. Hypoglycemic effect of Rheum ribes root in alloxan induced diabetic and normal mice. Scand J Lab Anim Sci. 2004:31:113-5. https://doi.org/10.3109/13880200903218935.

20. Walum E. Acute oral toxicity. Environ Health Perspect. 1998;106(Suppl 2): 497-503. https://doi.org/10.1289/ehp.98106497.

21. Chopra RN, Chopra IC. A review of work on Indian medicinal plants. Indian council of medical research, special report series no. 1; 1959. p. 99-107.

22. Anisuzzaman M, Rahman AHM, Harun-Or-Rashid M, Naderuzzaman ATM, Islam AKM. An ethnobotanical study of Madhupur, Tangail. J Appl Sci Res. 2007;3(7):519-30.

23. Koley TK, Walia S, Nath P, Awasthi OP, Kaur C. Nutraceutical composition of Zizyphus mauritiana Lamk (Indian ber): effect of enzyme-assisted processing. Int J Food Sci Nutr. 2011;62(3):276-9. https://doi.org/10.3109/09637486.2010.526930.

24. Karon B, Ibrahim I, Mahmood A, Huq M, Chowdhury MU, Rashid MA, et al. Preliminary antimicrobial, cytotoxic and chemical investigations of Averrhoa bilimbi Linn. and Zizyphus mauritiana Lam. Bangladesh Pharm J. 2011;14(2): 127-31

25. Hossain MJ, Sikder AA, Kaisar MA, Haque MR, Chowdhury AA, Rashid MA Phytochemical and biological investigations of methanol extract of leaves of Ziziphus mauritiana Lam. Boletín Latinoamericano Y Del Caribe De PlantasMedicinales Y Aromáticas. 2015;14(3):179-89. 
26. Vadivul R, Lakshmi KS. In-vitro and in-vivo anti-inflammatory activity of leaves of Symplocos cochinchnensis (lour) moore Ssp Laurina, Bangladesh. Pharmacol. 2008;3:121-31.

27. Shinde UA, Phadke AS, Nair AM, Mungantiwar AA, Dikshit VJ, Saraf MN Membrane stabilizing activity-a possible mechanism of action for the antiinflammatory activity of Cedrus deodara wood oil. Indian J Exp Biol. 1999;70:251-7. PMID:10641156.

28. Ramachandran G. Gram-positive and gram-negative bacterial toxins in sepsis: a brief review. Virulence. 2014;5(1):213-8. https://doi.org/10.4161/viru.27024.

29. Andrade RJ, Tulkens PM. Hepatic safety of antibiotics used in primary care. J Antimicrob Chemother. 2011;66(7):1431-46. https://doi.org/10.1093/jac/ dkr159.

30. Das S. Antimicrobial and antioxidant activities of green and ripe fruits of Averrhoa carambola Linn. and Ziziphus mauritiana lam. Asian J Pharm Clin Res. 2012:5:102-5.

31. Mbahi MA, Mbahi AM, Amos PI. Phytochemical screening and anti-diarrheal activity of the pulp and seed extracts of Ziziphus mauritiana in rats. Int J Biochem Res Rev. 2018;24(3):1-9. https://doi.org/10.9734/IJBCRR/2018/45674

32. Shettima AY, Sanda AF, Ali H, Bello RF, Modu B, Tijjani Y. Antidiarrheal effects of aqueous leave extract of Ziziphus mauritiana in wistar strain albino rats. Pharm Chem J. 2016;3(2):323-8.

33. Komal KS, Rana AC. Herbal apporaches for diarrhea: a review. Int Res J Pharm. 2013;4(1):31-8.

34. Robert A, Nezamis JE, Lancaster C, Hanchar AJ, Klepper MS. Enteropooling assay: a test for diarrhea produced by prostaglandins. Prostaglandins. 1976; 11(5):809-28. https://doi.org/10.1016/0090-6980(76)90189-1.

35. Lu TC, Huang YC, Lin P, Peng WH. Analgesic and anti-inflammatory activities of aqueous extract from Glycine tomentella root in mice. J Ethnopharmacol. 2007;113(1):142-3. https://doi.org/10.1016/j.jep.2007.05.024.

36. Rahman S. Antioxidant, analgesic, cytotoxic and antidiarrheal activities of ethanolic Zizyphus mauritiana bark extract. Orient Pharm Exp Med. 2011; 12(1):67-73. https://doi.org/10.1007/s13596-011-0042-2.

37. Hamiduzzaman M, Sarkar M, Hossain MJ, Rashid A. Neuropharmacological, analgesic, antidiarrheal and antimicrobial activities of methanolic extract of Ziziphus mauritiana leaves (rhamnaceae). Am J Adv Drug Deliv. 2014;2(2): 183-90.

38. Abubakar SM, Umar SA, Alexander I, Abubakar N, Abdulazeez MA, Sule MS. Evaluation of hypoglycaemic, hypolipidaemic and non-toxic effect of hydromethanolic extracts of Ziziphus mauritiana, Ziziphus spina christi fruit and glibenclamide on alloxan induced diabetic rats. J Drug Deliv Ther. 2018;8(3): 82-92. https://doi.org/10.22270/jddt.v8i3.1711.

39. Jarald EE, Joshi SB, Jain DC. Antidiabetic activity of extracts and fraction of Zizyphus mauritiana. Pharm Biol. 2009;47(4):328-34. https://doi.org/10.1080/ 13880200902752488

40. Bhatia A, Mishra T. Hypoglycemic activity of Ziziphus mauritiana aqueous ethanol seed extract in alloxan induced diabetic mice. Pharm Biol. 2010; 48(6):604-10. https://doi.org/10.3109/13880200903218935.

41. Ashraf A, Sarfraz RA, Anwar F, Shahid SA, Alkharfy KM. Chemical composition and biological activities of leaves of Ziziphus mauritiana $\mathrm{L}$ native to Pakistan. Pak J Bot. 2015;47(1):367-76.

\section{Publisher's Note}

Springer Nature remains neutral with regard to jurisdictional claims in published maps and institutional affiliations.

\section{Submit your manuscript to a SpringerOpen ${ }^{\circ}$ journal and benefit from:}

- Convenient online submission

- Rigorous peer review

- Open access: articles freely available online

- High visibility within the field

- Retaining the copyright to your article

Submit your next manuscript at $\boldsymbol{\nabla}$ springeropen.com 